NASA/TM-2003-212304

\title{
Effect of Voltage Level on Power System Design for Solar Electric Propulsion Missions
}

Thomas W. Kerslake

Glenn Research Center, Cleveland, Ohio 
Since its founding, NASA has been dedicated to the advancement of aeronautics and space science. The NASA Scientific and Technical Information (STI) Program Office plays a key part in helping NASA maintain this important role.

The NASA STI Program Office is operated by Langley Research Center, the Lead Center for NASA's scientific and technical information. The NASA STI Program Office provides access to the NASA STI Database, the largest collection of aeronautical and space science STI in the world. The Program Office is also NASA's institutional mechanism for disseminating the results of its research and development activities. These results are published by NASA in the NASA STI Report Series, which includes the following report types:

- $\quad$ TECHNICAL PUBLICATION. Reports of completed research or a major significant phase of research that present the results of NASA programs and include extensive data or theoretical analysis. Includes compilations of significant scientific and technical data and information deemed to be of continuing reference value. NASA's counterpart of peerreviewed formal professional papers but has less stringent limitations on manuscript length and extent of graphic presentations.

- TECHNICAL MEMORANDUM. Scientific and technical findings that are preliminary or of specialized interest, e.g., quick release reports, working papers, and bibliographies that contain minimal annotation. Does not contain extensive analysis.

- CONTRACTOR REPORT. Scientific and technical findings by NASA-sponsored contractors and grantees.
- CONFERENCE PUBLICATION. Collected papers from scientific and technical conferences, symposia, seminars, or other meetings sponsored or cosponsored by NASA.

- SPECIAL PUBLICATION. Scientific, technical, or historical information from NASA programs, projects, and missions, often concerned with subjects having substantial public interest.

- TECHNICAL TRANSLATION. Englishlanguage translations of foreign scientific and technical material pertinent to NASA's mission.

Specialized services that complement the STI Program Office's diverse offerings include creating custom thesauri, building customized databases, organizing and publishing research results ... even providing videos.

For more information about the NASA STI Program Office, see the following:

- Access the NASA STI Program Home Page at http://www.sti.nasa.gov

- E-mail your question via the Internet to help@sti.nasa.gov

- Fax your question to the NASA Access Help Desk at 301-621-0134

- Telephone the NASA Access Help Desk at 301-621-0390

- Write to:

NASA Access Help Desk

NASA Center for AeroSpace Information 7121 Standard Drive

Hanover, MD 21076 
NASA/TM-2003-212304

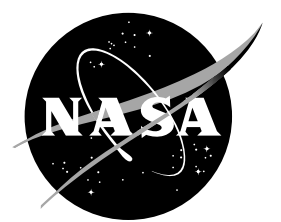

\section{Effect of Voltage Level on Power System Design for Solar Electric Propulsion Missions}

Thomas W. Kerslake

Glenn Research Center, Cleveland, Ohio

Prepared for the

International Solar Energy Conference

cosponsored by the American Society of Mechanical Engineers' Solar Energy Division, Japan Society of Mechanical Heat Transfer Division, Japan Solar Energy Society,

Korean Solar Energy Society, and CSIRO Australia

Kohala Coast, Hawaii, March 15-18, 2003

National Aeronautics and

Space Administration

Glenn Research Center 


\section{Acknowledgments}

The author acknowledges Dr. Ioannis "Yiangos" Mikellides and Dr. Gary Jongeward of SAIC for developing the expression for plasma electron collection current density, Mr. Andy Hoskins of General Dynamics

(Aerojet Corp.) for many productive technical discussions on high-voltage SEP systems and Mr. Ken Metcalf of Boeing Canoga Park for developing the detailed PMAD sizing spreadsheets.

This report is a formal draft or working paper, intended to solicit comments and ideas from a technical peer group.

This report contains preliminary findings, subject to revision as analysis proceeds.

Available from

NASA Center for Aerospace Information 7121 Standard Drive

Hanover, MD 21076
National Technical Information Service 5285 Port Royal Road Springfield, VA 22100 


\title{
EFFECT OF VOLTAGE LEVEL ON POWER SYSTEM DESIGN FOR SOLAR ELECTRIC PROPULSION MISSIONS
}

\author{
Thomas W. Kerslake \\ National Aeronautics and Space Administration \\ Glenn Research Center \\ Cleveland, Ohio 44135 \\ Phone: 216-433-5373 \\ Fax: 216-433-2995 \\ Email: Thomas.w.kerslake@nasa.gov
}

\begin{abstract}
This paper presents study results quantifying the benefits of higher voltage, electric power system designs for a typical solar electric propulsion spacecraft Earth orbiting mission. A conceptual power system architecture was defined and design points were generated for system voltages of $28-\mathrm{V}, 50-\mathrm{V}, 120-\mathrm{V}$ and $300-\mathrm{V}$ using state-of-the-art or advanced technologies. A 300-V "direct-drive" architecture was also analyzed to assess the benefits of directly powering the electric thruster from the photovoltaic array without up-conversion. Fortran and spreadsheet computational models were exercised to predict the performance and size power system components to meet spacecraft mission requirements. Pertinent space environments, such as electron and proton radiation, were calculated along the spiral trajectory. In addition, a simplified electron current collection model was developed to estimate photovoltaic array losses for the orbital plasma environment and that created by the thruster plume. The secondary benefits of power system mass savings for spacecraft propulsion and attitude control systems were also quantified. Results indicate that considerable spacecraft wet mass savings were achieved by the $300-\mathrm{V}$ and $300-\mathrm{V}$ direct-drive architectures.
\end{abstract}

\section{INTRODUCTION}

Solar Electric Propulsion (SEP) systems offer attractive spacecraft mass benefits for a range of Earth orbiting and interplanetary missions (Mason and Oleson, 2000, Sarver-Verhey et al., 2002 and Kerslake et al., 2000). In recent years, the trend has been toward increasing SEP system power levels (Reinhardt et al., 1998). As power levels increase, the spacecraft designer has greater motivation to select higher power system operating voltages to reap mass savings from smaller power cables and components. At the $300-\mathrm{V}$ level, it becomes possible to implement a "direct-drive" architecture whereby the main discharge chamber of a Hall Effect Thruster (HET) is powered without a stepup converter (Jongeward et al., 2001, 2002, and Hoskins et al., 2002). This Direct-Drive Hall Effect Thruster (D2HET) configuration greatly simplifies the thruster power processor design and offers additional mass savings. However, high voltage photovoltaic arrays must be designed with arc tolerance and to limit parasitic electron collection currents.

To quantify the benefits of higher voltage, power system designs were developed for a state-of-the-art, 10-kW spacecraft envisioned for a 270-day Earth orbit transfer mission. This conceptual spacecraft is illustrated in Figure 1. The power system architecture was defined and design points were generated for system voltages of $28-\mathrm{V}, 50-\mathrm{V}, 120-\mathrm{V}$ and $300-\mathrm{V}$. For each power system voltage design point, component technologies were chosen consistent with: (a) flight proven technologies and (b) advanced technologies available within the next 5 years. This paper discusses the power system design, modeling, and mission performance and the SEP spacecraft mass savings achievable with higher power system voltage levels.

\section{POWER SYSTEM DESIGN}

\section{Power System Requirements}

The Electric Power System (EPS) design must provide $10-\mathrm{kW}$ to the HET system, during orbital Sun periods only, over the course of the spiraling mission phase. This phase typically requires 3 - to 9-months. In addition, the EPS must provide $0.4-\mathrm{kW}$ continuously throughout the life of the mission to power spacecraft house keeping functions and payloads. If required, the spacecraft EPS can then support a multi-year GEO mission at a nominal power level of $10-\mathrm{kW}$. 


\section{PMAD Architecture}

The Power Management and Distribution (PMAD) architecture is shown in Figure 2. In this direct-energy transfer architecture, there are two Photovoltaic Array (PVA) wings to generate electric power. Each wing is connected to an Array Regulator Unit (ARU), to control EPS voltage, and a Solar Array Drive Assembly (SADA), to articulate the wing for Sun tracking and transfer power via slip rings. SADA power is fed into the Main Distribution Panel (MDP) that provides switching for propulsion system and spacecraft loads. In addition, the MDP provides fault detection/isolation and grounding of EPS components to the spacecraft chassis. Spacecraft power is fed to the Power System Enclosure (PSE) that contains an isolation diode, a battery charge unit, a DC-to-DC Converter Unit (DDCU) and a Remote Power Controller Module (RPCM) for spacecraft load switching and fault protection. The SADA controller unit is also housed in the PSE.

While spacecraft loads are assumed to operate at $28-\mathrm{V}$, the spacecraft primary power bus voltage is treated as a parameter with values of $28-\mathrm{V}, 50-\mathrm{V}$, $120-\mathrm{V}$ or $300-\mathrm{V}$. The rationale for choosing these voltage levels is as follows. $28-\mathrm{V}$ was selected based on long standing flight heritage. $50-\mathrm{V}$ was chosen to match the operating voltage of VAriable Specific Impulse Magnetoplasma Rocket (VASIMR) thruster radio frequency plasma generators (Baity, 1999). The VASIMR electric propulsion technology was included as part of the NASA Radiation and Technology Demonstration (RTD) Project flight experiment study. $120-\mathrm{V}$ was selected to match operating high-voltage power systems on NASA spacecraft, i.e. the International Space Station (ISS) EPS secondary bus and the Terra spacecraft primary bus (Kurland et al., 2000). 300-V was selected since this is the lowest practical voltage to directly operate a HET without upconversion. The impacts of selecting a $300-\mathrm{V}$ voltage level on component designs and PMAD architecture are shown in Table 1. The main impacts include the need for an ARU, the PPU design and location of the battery, i.e. tied to the EPS primary (high) or secondary (low) voltage level.

\section{Photovoltaic Array}

The State-of-the-Art (SOA) PVA wings consist of deployable rigid-panels populated with three-junction GaInP2/GaAs/Ge solar cells (Spectrolab, 2002) used on today's high power satellites, such as the Lockheed Martin A2100 (Ehsani and Salim, 2000). Consistent with past work (Kerslake et al., 2000), 25\% efficient solar cells are utilized and covered with massoptimized, 10-mil thick ceria-doped coverslides. Panels are constructed of composite face sheets bonded to a 1-inch thick aluminum honeycomb core. The power harness consists of multiple flat copper conductors sized to allow a $3 \%$ voltage drop and sandwiched in layers of polyimide. The PVA mass has a calculated mass density of $3-\mathrm{kg} / \mathrm{m}^{2}$ including a $10 \%$ factor for panel hinges, fittings and tie-down/release hardware. The SADA specific mass, $0.6-\mathrm{kg} / \mathrm{kW}$, is based on the Moog Type 2 SADA (Moog, 2002).

The SOA+5-year PVA wings consist of multiple, open-weave gore panels that deploy like an umbrella and are populated with $29 \%$ efficient multi-junction cells. This design is based on that reported by Jones (1993) and built for the Mars 2001 Lander spacecraft. The PVA has a total calculated mass of $1.8-\mathrm{kg} / \mathrm{m}^{2}$.

\section{Energy Storage}

The energy storage subsystem is based on electrochemical battery cells. Both nickel-hydrogen $\left(\mathrm{NiH}_{2}\right)$ individual pressure vessel and lithium ion battery cell technologies are considered. Cell properties, such as charge/discharge efficiencies, charge/discharge voltage limits, dimensions, mass, and operating temperature range, are obtained from commercial battery product data sheets (Eagle Picher, 2002, and AEA Technology, 2002). For this mission, a modest 1000-cycle cell life is required. Cells are seriesconnected and housed in an aluminum enclosure to afford environmental protection and enhance thermal control. The battery mass is calculated at 1.1 times the cell mass to account for cell interconnects, by-pass diodes, cell voltage control (Li-ion only), cell heaters, the enclosure and connectors. The SOA+5-year battery assumes cells with $10 \%$ improved W-hr/kg performance and a carbon-carbon material enclosure.

\section{Power Electronics}

ARUs contain multiple shunt elements that are switched on or off for coarse voltage regulation. The last shunt element is pulse-width modulated for fine voltage control $(<1 \%$ ripple). Shunt elements are controlled by generating a voltage error signal used by switch gate control logic. The ARU contains input/output filtering and a PVA string blocking diode board. The MDP contains two input and three output hybrid switches and control electronics. Each switch consists of an electro-mechanical contactor in parallel with a solid state switch (MOSFET) and a current sensor. The PSE contains a notional solid-state charge limiting BCU, a $92 \%$ efficient DDCU and a 10 -channel RPCM based on MOSFET switches. All components are mounted within aluminum enclosures with the associated control/monitoring electronics, power harnessing and thermal control (cold plates and heaters). The SOA+5-year power electronics are assumed to have a $10 \%$ improved $\mathrm{kW} / \mathrm{kg}$ power density and carbon-carbon enclosures. Power cabling consists 
of twisted-pair copper conductors with ethylene tetrafluoroethylene insulation.

Power electronic component and power cable masses were estimated using two separate approaches. The first approach, was to use a simplified mass-power scaling of similar ISS components (Kerslake et al., 2000) while cable conductor gauge sizes were selected based on number of parallel conductors (two hot, two ground), operating temperature $\left(100^{\circ} \mathrm{C}\right)$ and bundled, vacuum current derating. In the second approach, component masses were estimated using a more sophisticated spread-sheet model. This model, derived from ISS power electronics designs, breaks down components into major subassemblies and utilizes mass curve fits based on design requirements and technology options (Metcalf, 1992 and Metcalf, 2002). In this approach, power cables were sized based on specified materials, efficiency (voltage drop) and the redundancy specified.

\section{ANALYSIS}

The spacecraft and orbit trajectory were designed to meet the RTD mission requirements (Kerslake et al., 2000). However, this class of SEP mission has generalized applicability to a range of Earth science missions, interplanetary missions, micro-satellite and propulsion technology demonstrations and geosynchronous commercial and military satellites. A brief description of spacecraft system analyses and mission orbit mechanics analysis is given in the following sections.

\section{Mission Design}

Trajectory The mission entails launching a $\sim 1500-\mathrm{kg}$ (wet mass) spacecraft into a $400-\mathrm{km}, 51.6^{\circ}$ inclination, circular low Earth orbit (LEO). This is followed by a $\sim 270$-day spiral transfer orbit to 35,000$\mathrm{km}$ equatorial orbit (nearly GEO). This maneuver is accomplished using a $10-\mathrm{kW}$ electric propulsion system operating only during orbital Sun periods and thrusting tangential to the orbit plane. Phased, out-of-plane thrusting is used to achieve the inclination change. During the planar spiral out, micro-satellites are deployed to provide simultaneous radiation measurements of various Van Allen Trapped Radiation Belt locations. The spacecraft mission altitude history is shown in Figure 3.

To estimate the impact of shadowing and launch date on the performance, the computer program SEPSPOT (Sackett, 1975) was used. This program used orbital averaging and solved for the minimum time trajectory between two closed conic orbits. Low-thrust trajectories were generated using the Glenn Research Center's high fidelity integrator "SNAP" which incorporated an eighth order Runge-Kutta integrator and the JPL DE403 Ephemeris file of the solar system.
Earth shadow crossings were precisely modeled and an eighth order earth gravity model was used along with solar and lunar gravitational effects. EPS sizing (affects spacecraft initial mass) and mission trajectory (affects PVA degradation) analyses were performed iteratively until a converged solution was obtained.

Electric Propulsion System The spacecraft is equipped with a $10 \mathrm{~kW}$ HET system that operates at a 2,100 -second specific impulse and a 54\% combined thruster/PPU efficiency with xenon propellant. The electric propulsion system includes a propellant storage and flow control system and a Power Processing Unit (PPU). The PPU consists of an input EMI filter, the high power main anode discharge supply (with a boost converter), the lower power heater/keeper/magnet supply, auxiliary supplies and control electronics for the PPU and xenon flow control system. The PPU is actively cooled using an ammonia loop heat pipe system (Dynatherm, 2002) and a deployable rigid panel radiator. For $1000-\mathrm{W}$ of heat rejection, the estimated loop mass was $14-\mathrm{kg}$ while the estimated radiator mass was $30-\mathrm{kg}$ for a $44-\mathrm{kg}$ total mass.

If the spacecraft EPS bus voltage is $300-\mathrm{V}$, a "direct-drive" PPU configuration is possible. In this case, filtering requirements are reduced and the main discharge converter is eliminated with an attendant electrical efficiency gain and reduced thermal dissipation requirement. This results in a $50 \%$ savings in PPU mass and heat rejection as well as reduced unit cost and complexity. Hoskins et al. (2002) provides an excellent review of "direct-drive" EPS and SEP system benefits.

Spacecraft Flight Mode and Attitude Control The nominal spacecraft flight mode has the thruster axis in the orbit plane and tangential to the orbit ellipse. The solar array wings are perpendicular to the orbit plane and rotate about a single axis. This nominal flight mode is used for absolute solar beta angles, $|\beta|$, less than $25^{\circ}$, where $\beta$ is the angle between the orbit plane and Earth-Sun line. During this flight mode, solar array cosine pointing losses are limited to $9 \%$.

For $|\beta|$ greater than $25^{\circ}$, the spacecraft switches to a so-called "yaw-steering" flight mode (Chetty, 1991 and Hosken \& Wertz, 2002). For this mission, the flight mode is more properly called "roll-steering" as the spacecraft rolls about the thruster axis (maintained in plane and tangent to the orbit ellipse). This type of spacecraft steering was studied for a solar electric transfer vehicle mission (Jenkin, 1992). The spacecraft is rolled through an angle $\leq 2 *\left(90^{\circ}-|\beta|\right)$ in one-half orbit period such that the combined spacecraft roll angle and single axis SADA rotation enables Sun-tracking PVA pointing. 
The spacecraft Attitude Control System (ACS) consists of $50 \mathrm{~N}-\mathrm{m}-\mathrm{sec}$ momentum wheels, a hydrazine monopropellant propulsion system (220-sec specific impulse) for momentum wheel desaturation, attitude sensors and control electronics. ACS jet thrust level and total propellant requirement were estimated based on engineering calculations for spacecraft maximum disturbance torques (Wertz and Larson, 1999) and roll steering torques. These torques would generally act about all three spacecraft axes, but for simplicity, were conservatively assumed to act additively about a single axis. Contributing disturbances included gravity gradients, aerodynamic drag, thruster misalignment, solar pressure and magnetic torques, in order of magnitude. Orbital momentum accumulation was also calculated.

\section{Orbital Environment Modeling}

Earth orbit environments affect PVA design and performance markedly. The largest contributor to PVA cell degradation is radiation damage from energetic protons and electrons trapped in the Earth's magnetic field. The fluences and energy spectra of these particles was determined using the AP-8/AE-8 models (Jordan, 1989). A secondary contributor to PVA degradation is impact damage for meteoroids and debris. Meteoroid fluences were calculated using the Cour-Palais model (Cour-Palais, 1969) while debris population fluences were determined using the Kessler model (Kessler et al. 1989, 1996). The resulting impact damage and solar cell electrical performance loss were determined using empirical models (Eichelberger and Kineke, 1967, and Myre, 1991).

Electron Collection Model Conventional PVA designs that are negatively grounded to the spacecraft chassis and that operate at voltages above $\sim 120-\mathrm{V}$ will collect electrons from the ambient and induced (HET plume) plasma environments. This results in a parasitic current loss that reduces solar cell string current. This parasitic current can become a major PVA design driver for high voltage arrays operating in the vicinity of high density plasmas created by electric propulsion thrusters. As such, plasma electron current collection must be modeled. However, current collection physics are complex and are still the focus of research (Jongeward, 2002). Thus, for the purpose of these EPS parametric studies, a conservative engineering approach to modeling current collection was adopted.

A preliminary, empirical model for solar cell plasma current collection, $\mathrm{I}_{\mathrm{c}}$ (amps), for voltages, $\mathrm{V}$, up to $300-\mathrm{V}$, was formulated as:

$$
I_{c}=F * A_{c} * J_{c}
$$

where $F$ is an empirical "integral factor," $A_{c}$ is the exposed solar cell edge collection area $\left(\mathrm{m}^{2}\right)$ and $J_{c}$ is the plasma electron collection current density $\left(\mathrm{amp} / \mathrm{m}^{2}\right)$. For the two-dimensional, orbit-limited case ignoring potential barriers, $\mathrm{J}_{\mathrm{c}}$ can be approximated as:

$$
\mathrm{J}_{\mathrm{c}}=\mathrm{J}_{\mathrm{th}} *[4 * \chi / \pi]^{* *} 0.5,
$$

where $\chi=\mathrm{e}^{*} \mathrm{~V} /\left(\mathrm{k}^{*} \mathrm{~T}_{\mathrm{e}}\right)>1$ (Laframboise \& Parker, 1973, and Mikellides, 2002). $\mathrm{J}_{\text {th }}$ is the plasma electron thermal current density $\left(\mathrm{amp} / \mathrm{m}^{2}\right)$ given by:

$$
\mathrm{J}_{\mathrm{th}}=\left(\mathrm{N}_{\mathrm{e}} * \mathrm{e} / 4\right) *\left[8 * \mathrm{k}^{*} \mathrm{~T}_{\mathrm{e}} /\left(\pi^{*} \mathrm{~m}\right)\right]^{* * 0} 0.5 .
$$

In the above equations, $\mathrm{e}$ is the electron unit charge, $\mathrm{m}$ is the electron mass, $\mathrm{k}$ is the Boltzmann constant and $\mathrm{N}_{\mathrm{e}}$ and $T_{e}$ are the orbit altitude-dependent electron number density $(\# / \mathrm{m} 3)$ and temperature $(\mathrm{K})$, respectively. For the ambient plasma, the approximate average orbit altitude-dependence of $\mathrm{N}_{e}$ and $\mathrm{T}_{\mathrm{e}}$ are given by (Smith and West, 1983 and Anon., 1991). The induced plasma environment at a PVA surface from an operating HET depends on the thruster design and the spacecraft configuration. For the current study, reasonable estimates can be derived from Jongeward (2001) that $\mathrm{N}_{\mathrm{e}} \sim 2.5 \mathrm{E} 13$ \#/m3 and from Gallimore et al. (2001) and Myers and Manzella (1994) that $\mathrm{T}_{\mathrm{e}} \sim 2.5 \mathrm{eV}$ (or 29,000 $\mathrm{K})$.

The electron collection area is given by:

$$
\mathrm{A}_{\mathrm{c}}=2 *(\mathrm{~L}+\mathrm{W}) * \delta * \# \text { cells, }
$$

where $\mathrm{L}$ is the solar cell edge length $(\mathrm{m}), \mathrm{W}$ is the solar cell edge width $(\mathrm{m}), \delta$ is the solar cell thickness and \#cells is the number of series-connected cells in the solar cell string.

The empirical integral factor, F, represents the average current collected from voltages 0 to $\mathrm{V}_{\max }$ $(=300-\mathrm{V})$, divided by the maximum current collected at $\mathrm{V}_{\text {max }}$. This accounts for the distribution of cell voltages in a solar cell string and the different charging phenomena that take place as voltage increases, i.e. barrier formation and snap-over behavior. Current collection data versus voltage were obtained with a representative solar cell string coupon during ground testing with a laboratory-generated plasma (Jongeward 2001). These data nicely fit a power-law equation. The average current collection was thus determined by integrating the power-law equation and dividing by the voltage range $=\mathrm{V}_{\max }$. The maximum current collected was determined by evaluating the power-law equation at $\mathrm{V}_{\max }$. The resulting value of $\mathrm{F}$ was found to be 0.33 .

\section{Power System Computational Methods}

A dedicated Fortran code was developed to predict power system performance and estimate system mass. EPS component design and mission information were 
read in via data input files. Mission data, provided at 15-minute intervals throughout the 270-day mission, included spacecraft position/velocity, Sun/Earth angles, orbit sun/eclipse indicator, insolation strength and local particulate radiation fluences. This information was used to calculate environmental heating rates, solar cell equivalent radiation dose (Anspaugh, 1996 and Marvin, 2000), solar cell micrometeoroid/orbital debris damage area and ambient plasma electron collection current.

EPS performance analysis was performed in a time-stepping, load-driven fashion. Based on load demand and set point voltages, PMAD system currents and voltages were calculated for the current time step. Component and cable losses were calculated based on input resistances, diode voltage drops and converter efficiency (if present). PVA string current was iteratively determined to satisfy solar cell and ARU voltage and current constraints. The number of string series-connected solar cells was determined iteratively such that cell operating voltage was no larger than maximum power voltage throughout the mission. The number of strings per wing was also determined iteratively such that minimum number of shunted strings was $<3$. This minimized array area while ensuring that the ARU can maintain sun time voltage regulation throughout the mission.

Solar cell electrical performance was modeled using a single exponential current-voltage (IV) function that was adjusted for operating temperature, illumination intensity, PVA sun pointing error and flatness, coverslide transmittance, environmental degradation and cell mismatch. Solar cell IV operating point and temperature were iteratively determined. Cell operating temperature was calculated using a lumpmass, transient thermal model accounting for environmental heating/cooling, electrical power extraction and interconnect wiring ohmic heating. Array area was calculated as the total solar cell area divided by a packing factor, 0.85. A wing length-towidth ratio of 6 was selected to obtain a width of approximately $2-\mathrm{m}$ that corresponds to the approximate length of the spacecraft microsat storage section (see Figure 1).

The battery was sized based on the input design characteristics of Table 2. These inputs were used to calculate the number of cells, cell capacity, design Depth-Of-Discharge (DOD), design charge/discharge rates and trickle charge rate. For mission analysis, the battery charge and discharge rates were determined based on the required load, battery charge and discharge efficiencies and the orbit sun and eclipse time. For orbits with little or no eclipse period, the battery charge current was set to a trickle charge value $(\mathrm{C} / 50)$.

The bulk temperature of EPS components was also calculated using a simplified, lumped-mass transient model. Calculated values of component power dissipation and environmental heating were used to determine operating temperatures and the required thermal control heating or cooling to satisfy operating temperature limits.

\section{RESULTS AND DISCUSSION}

\section{EPS Performance}

The EPS component performance most affected through the mission was that of the PVA. A profile of PVA power is shown in Figure 4. The results shown are for the 120-V PMAD case but are indicative of the behavior of the array at other voltage levels as well. At the start of the mission, the full array power capability exceeds the delivered power requirement and thus, excess power is shunted in the ARU. Between mission days 25 and 75, a large drop in array power is seen followed by a more gradual decay throughout the remainder of the mission. By the end of the mission, the array full power capability is just slightly more than the delivered power (by design). The primary cause of array power degradation is solar cell radiation damage. This is evident in Figure 5 that plots various PVA current degradation components (voltage degradation components were similar). During mission days 25 through 75, the spacecraft is crossing the most energetic region of the trapped proton belts at high magnetic latitude (orbital altitude of approximately $2000-\mathrm{km}$ to $7500-\mathrm{km})$. High energy protons are particularly damaging to the solar cell electrical performance.

As the solar cells incur radiation damage, the array voltage capability is degraded and individual cells must operate at a relatively higher operating voltage to meet the PMAD voltage set point. This effect is seen in Figure 6 that plots the voltage ratio of solar cell operating voltage to peak power point voltage ( $\mathrm{Vmp}$ ). This voltage ratio starts at $\sim 0.9$ at the beginning of the mission with a fresh array and then approaches a value of $\sim 1.0$ (by design) on mission day 75 after sustaining radiation damage. Throughout the remainder of the mission, the voltage ratio recovers (decreases) slightly in response to cooler array operating temperatures that offer higher Vmp. Array temperatures and several PMAD box temperatures are shown in Figure 7. After mission day 100, the spacecraft no longer encounters Earth eclipses and extreme cold temperatures. For the remainder of the mission as altitude gained, thermal interactions with the Earth are diminished and component temperatures gradually cool off.

Using multilayer insulation and thermal control coatings, calculated component electrical heating and active cooling thermal loads to keep hardware within acceptable operating temperature limits were negligible. For each power electronics box, the calculated values 
for dissipated heat and parasitic heat (i.e., power supply), respectively, were small: $123-\mathrm{W} / 63-\mathrm{W}$ for the ARU, 126-W / 80-W for the MDP and 88-W / 70-W for the PSE. With proper heat sinking, passive cooling is a reasonable assumption for the ARU and PSE. For the MDP, heat dissipation is localized at the switches and may require an active cooling cold plate interface to stay below semiconductor maximum operating temperature limits.

\section{Impact of PMAD Voltage}

Power system mass and sizing results for this SEP mission are shown in Table 3 as a function of EPS primary PMAD voltage. EPS technology assumptions and mass estimates were kept consistent with those of Kerslake et al. (2000). These results show that EPS mass decreases with increasing voltage. With higher voltages, current levels are reduced as are voltage losses throughout the system. With reduced currents, conductors can be sized smaller and mass saved. Lower system power losses allow for a smaller PVA active area and smaller power harness mass. These reductions, in turn, allow for a reduction in PVA ancillary structure mass and perhaps a reduction in PVA panel mass (though not assessed in this study). EPS mass reductions are approximately proportional to voltage level. Referenced to the $120-\mathrm{V}$ case, the $50-\mathrm{V}$ EPS is $19 \%$ more massive while the $300-\mathrm{V}$ EPS is $17 \%$ less massive.

The battery mass did not vary monotonically with PMAD voltage level for three reasons. First, the battery design approach assumed the use of existing aerospacequalified cell designs (Eagle Picher, 2002, and AEA Technology, 2002) with discrete amp-hr capacities. The cell capacity selected had to be equal to, or greater than, the required cell capacity calculated. Thus, the battery mass depends on how closely the required capacity is matched to an existing cell product. For example, the $50-\mathrm{V} \mathrm{NiH}$ battery required capacity was 17.6-amp-hr and matched well with a 20 amp-hr cell. But the $28-\mathrm{V}$ battery required a $31 \mathrm{amp}-\mathrm{hr}$ capacity which could only be matched with a 50 amp-hr cell. Thus, the $28-\mathrm{V}$ battery mass was considerably more than the $50-\mathrm{V}$ battery. The impact of non-optimum battery size on EPS mass was also discussed by Gaddy, 1995.

The second reason for non-monotonic battery mass was that cell performance varied with cell capacity. For example, a $20 \mathrm{amp}-\mathrm{hr} \mathrm{NiH}_{2}$ cell has a specific energy of $42-\mathrm{W}-\mathrm{hr} / \mathrm{kg}$ while that of a 76 amp-hr cell is $52-\mathrm{W}-\mathrm{hr} / \mathrm{kg}$. The third reason applies only to the $300-\mathrm{V}$ battery options whereby the battery design is dramatically affected by the decision to locate the battery on the input side or output side of the DDCU. At $300-\mathrm{V}$, the $\mathrm{NiH}_{2}$ battery requires 201 seriesconnected cells which introduces reliability concerns.
To address this issue, the $\mathrm{NiH}_{2}$ battery could be relocated to the DDCU $28-\mathrm{V}$ output side and use the DDCU for charge control. This has the advantage of decoupling the battery design from the primary power bus voltage and allows the designer to tailor the secondary power bus voltage to the available battery cell capacity (Button, 2003). But without discharge control electronics, the spacecraft payloads will see a variable eclipse time voltage. However, these payloads could employ commercially available power converters already designed to handle the $25 \%$ voltage variation during battery discharge. Alternatively, for a modest mass penalty, battery discharge voltage could be regulated with a Series Connected Boost Regulator (Button, 1998).

Another approach for a $300-\mathrm{V}$ battery would be to select lithium ion cell technology with three times the average cell voltage capability compared to $\mathrm{NiH}_{2}$ cells. With lithium ion cells, a reasonable 74 series-connected cells are required which is comparable to the 76 seriesconnected $\mathrm{NiH}_{2}$ cells flying on the ISS US-segment EPS (Dalton and Cohen, 2002).

Power cable masses also did not scale truly proportional to PMAD voltage for two reasons. First, a ground rule was imposed to limit minimum conductor size to AWG 20 (for robustness). Thus smaller, lower mass conductors could not be used even if current levels permitted. This limit was reached in the MDP to PSE power cable set at a PMAD voltage of $50-\mathrm{V}$. Second, as the conductor size decreased and voltage level increased, the insulation mass fraction of cable increased. This tended to off-set the mass savings in copper conductor mass.

The $300-\mathrm{V}$ direct-drive system offered an $11 \%$ decrease in EPS mass compared to the nominal 300-V system. There are two primary savings afforded to the EPS by implementing a direct-drive system. First, the PPU converter unit was removed increasing the box efficiency by 5 percentage points. This reduced the EPS power requirement by $500-\mathrm{W}$ allowing for a smaller PVA area and mass. Second, the HET xenon flow control assembly was used to regulate primary PMAD voltage. This allowed the ARUs to be eliminated with an attendant $11-\mathrm{kg}$ mass savings. In addition to EPS mass savings, the direct-drive HET system also realized mass savings of $17-\mathrm{kg}$ in the PPU (without converter) and $15-\mathrm{kg}$ in radiator mass from the PPU active thermal control system. Note that it would be possible to employ HET xenon flow control for primary bus voltage regulation for the $28-\mathrm{V}, 50-\mathrm{V}$ and $120-\mathrm{V}$ voltage options. This would allow elimination of the ARUs, saving mass, but the PPU converter magnetics would have grow in mass to handle the resulting input voltage variations (Button, 2003).

To improve EPS mass estimates and reconfirm the PMAD voltage trends discussed above, more detailed 
models for sizing power electronics and power cabling were utilized (Metcalf, 2002). These models were run separately from the dedicated Fortran code, but used component current/voltage results from the Fortran code as inputs. Results are presented in Table 4 for SOA technologies and SOA+5-year technologies.

The overall trends of reduced EPS mass with increasing voltage and mass benefits from the directdrive architecture are still evident. However, the PMAD box and cables masses calculated were greater, while the mass savings realized with higher voltages were more modest. For the example comparing SOA $120-\mathrm{V}$ $\mathrm{NiH}_{2}$ system to the $300-\mathrm{V}$ lithium ion system, a $28 \%$ mass savings was calculated using simple scaling rules whereas only a $15 \%$ mass savings was calculated using the detailed PMAD component sizing models. The primary reasons for the more modest PMAD box mass savings are: (1) the enclosure \& cold plate mass scale only weakly with component voltage level and (2) box ancillary components (power supply, control and monitoring card, local data interface, harnesses and sensors) are essentially independent of PMAD operating voltage. The mass savings of direct-drive for a $300-\mathrm{V}$ PMAD was $15 \%$. Assuming SOA+5-year technology (Table 4b), the PMAD voltage versus EPS mass trends and direct-drive mass savings remain the same. The largest difference afforded by advanced technologies was mass savings in the PVA. The openweave, multi-gore design with its highly efficient structure and higher efficiency / cooler operating cells, had a calculated mass nearly half that of the rigid panel SOA PVA designs. This is in spite of higher end-ofmission radiation dose (damage equivalent $1-\mathrm{MeV}$ electron fluence of $6.0 \mathrm{E} 14 / \mathrm{cm}^{2}$ compared to a fluence of $4.0 \mathrm{E} 14 / \mathrm{cm}^{2}$ for the rigid panel).

The improved power cable mass estimates, although slightly higher, compare reasonably well with the original mass estimates, except for the $300-\mathrm{V}$ case. In the original mass estimate, insulation mass was scaled with conductor mass, whereas the improved model sized insulation thickness (mass) based on limiting electric field strength to half that of the insulator dielectric strength. With smaller conductor gauge size at $300-\mathrm{V}$, the improved model calculates a more representative insulation mass than the previous scaling approach.

\section{Plasma Electron Collection Currents}

PVA electron collection currents were negligible for array operating voltages of $120-\mathrm{V}$ or less. For the $300-\mathrm{V}$ array designs, electron collection current was dominated by the HET induced plasma environment. The maximum calculated collection current was $4.6 \%$ of the PVA operating current. The maximum ambient current collection, only $0.4 \%$ of the PVA operating current, occurred at the start of the mission in LEO when electron number density was highest. Thus, for a 40-amp PVA peak operating current, approximately 2-amps of parasitic electron current was collected. Therefore, to maintain the spacecraft chassis near plasma potential, the HET cathode must operate at a 2amp higher current level.

If the HET is not operating, the ARU will shunt the majority of PVA strings and the electron collection current will decrease proportionally. In a direct-drive HET configuration, it is possible to operate the cathode only in a "plasma contractor" mode to maintain spacecraft chassis potential close to plasma neutral. Such an approach has minor design penalties since slightly more xenon propellant is required as is a slightly more complex, dual propellant flow control assembly to separately control xenon flow to the HET anode and cathode.

\section{Spacecraft Attitude Control System}

The calculated mass and PVA area savings from higher PMAD voltages and a direct-drive architecture result in a modest improvement in the spacecraft ACS mass. A summary of spacecraft mass properties, torques and momentum values are shown in Table 5 for the SOA and SOA+5-year EPS technologies. Torque and momentum values shown are for the most demanding part of the mission at the lowest orbit altitude of $400-\mathrm{km}$.

Spacecraft moment-of-inertia and environmental disturbance torques are dominated by the PVA mass and dimensions. Thus any array mass or size savings afforded by PMAD voltage or direct-drive configuration results in an ACS mass savings. These mass savings are driven by reduced hydrazine propellant and tankage mass from fewer autonomous desaturation burns for momentum dumping. For the $120-\mathrm{V}$ SOA case, approximately $68-\mathrm{kg}$ of propellant was required for momentum dumping over the mission duration. More frequent momentum dumps were required for the larger, lower voltage PVA cases, but as the spacecraft spirals out to higher altitude, the disturbance torques acting on the arrays quickly diminished. Therefore, the overall propellant savings from the $120-\mathrm{V}$ case over the $28-\mathrm{V}$ is only about $5 \%$ (about $4-\mathrm{kg}$ of hydrazine and tankage). Increasing voltage level above $120-\mathrm{V}$ offered very little propellant mass savings. Similar trends were observed for the $\mathrm{SOA}+5$-year EPS technologies although spacecraft momentum management requirements were greatly reduced by the low-mass, circular-geometry, advanced technology PVAs. For this mission, the HET thrust offset torque dominated the spacecraft accumulated momentum term and thus, the added mass and complexity of a thruster gimballing is likely justified. 


\section{Overall Spacecraft Mass Savings}

For the mission studied, the spacecraft wet-mass to dry-mass ratio is about 1.4 . Thus, for every $1-\mathrm{kg}$ saved in spacecraft dry-mass, $1.4-\mathrm{kg}$ is saved in spacecraft wet-mass. For the SOA EPS, a 46-kg mass savings was obtained when increasing PMAD voltage from $120-\mathrm{V}$ to $300-\mathrm{V}$. This translates into a $22-\mathrm{kg}$ savings in xenon propellant and tankage and a spacecraft wet-mass reduction of $68-\mathrm{kg}$. Introducing direct-drive saves $39-\mathrm{kg}$ for $300-\mathrm{V}$ EPS and 32-kg in the PPU and PPU heat rejection radiator. This translates to a $33-\mathrm{kg}$ savings in xenon propellant and tankage and a spacecraft wet mass savings of $104-\mathrm{kg}$ from directdrive alone. Introducing SOA+5-year EPS technology to a $300-\mathrm{V}$ direct-drive system saves $84-\mathrm{kg}$ of mass which translates into a $123-\mathrm{kg}$ spacecraft wet mass savings. A fraction of these mass savings could be put into greater payload mass. Alternatively, the mass savings could enable a shorter LEO to GEO transfer time or perhaps a launch to orbit on a smaller, less costly launch vehicle.

\section{SUMMARY AND CONCLUDING REMARKS}

A dedicated Fortran EPS performance code was used in concert with spreadsheet models to quantify the potential mass benefits of high voltage spacecraft power systems and a direct-drive architecture for a representative, Earth-orbiting solar electric propulsion mission. Results showed that spacecraft EPS mass decreased as PMAD voltage was increased over the range of $28-\mathrm{V}$ to $300-\mathrm{V}$. The mass savings from higher voltage, lower current were achieved by the use of lighter power cabling and component down-sizing due to lower system losses. Results from a simplified model showed that 300-V PVA plasma electron current collection was less than $5 \%$ of the array operating current. Further mass benefits were afforded by the direct-drive architecture by eliminating the ARU, removing the PPU converter, reducing the PPU heat rejection radiator and down-sizing EPS components due to lower system losses. These mass benefits were achieved assuming either SOA or advanced EPS technologies. The impact of EPS and propulsion subsystem mass savings on the spacecraft ACS system was also calculated. Results showed that mass savings of a $120-\mathrm{V}$ system over that of a $28-\mathrm{V}$ system can save only a few percent in ACS propellant mass over the mission duration. Further increases in voltage and direct-drive implementation offer very little added ACS propellant mass savings. However, increasing system voltage from $120-\mathrm{V}$ to $300-\mathrm{V}$ reduced spacecraft dry mass to save $68-\mathrm{kg}$ in spacecraft wet mass (out of an initial $1500-\mathrm{kg}$ total wet mass) and implementing direct-drive saved an additional 104-kg of wet mass. These added mass savings were achieved by reduced xenon propellant and tankage mass in the spacecraft primary electric propulsion system.

\section{REFERENCES}

AEA Technology Website, 2002, http://www.aeatspace.com/prodsys/subdivisions-div/SPBAT1.html

Anon., 1991, "Space Station Ionizing Radiation Emission and Susceptibility Requirements for Ionizing Radiation Environment Compatibility," SSP30512.

Anspaugh, B. E., 1996, "GaAs Solar Cell Radiation Handbook," NASA-CR-203421, Jul 01.

Baity, F. W., et al., 1999, "Design of RF Systems for the RTD Mission VASIMR," ORNL/CP-103576, April 12.

Button, Robert M., 1998, “A Modular PMAD System for Small Spacecraft," NASA TM-1998-206628, January.

Button, Robert M., 2003, NASA Glenn Research Center, personal communication, February.

Chetty, P.R.K., et al., 1991, "TOPEX Electrical Power System," $26^{\text {th }}$ Intersociety Energy Conversion Engineering Conference, August 4-9, 1991.

Cour-Palais, B. G., 1969, "Meteoroid Environment Model -1969 (Near Earth to Lunar Surface)," NASA SP 8013.

Dalton, P., and Cohen, F., 2002, "International Space Station Nickel-Hydrogen Battery On-orbit Performance," NASA TM-2002-21172, July.

Dynatherm Website, 2002, http://www.dynathermdci.com/lhpcap.htm

Eagle Picher Website, 2002, http://www.epitech.com/index.htm

Ehsani, M. and Salim, A., 2000, "Flawless In-orbit Performance of Lockheed Martins' Premier A2100 Electrical Power Subsystem for Communications Satellites," AIAA-2000-2809, 35 $5^{\text {th }}$ Intersociety Energy Conversion Engineering Conference, Las Vegas, NV, July 24-28.

Eichelberger, R. J., and Kineke, J. H., Jr., 1967, "Hypervelocity Impact," SPRINGER-VERLAG, Jan 1, p. 659-692.

Gallimore, A. D., et al., 2001, "Experimental Investigations with a 5-kW-Class Laboratory Model Closed-Drifted Hall Thruster," AFRL-SR-BL-TR01-0069, Jan 01.

Gaddy, E. M., 1995, "Cost Trade Between MultiJunction, Gallium Arsenide, and Silicon Solar Cells," Proceedings of the Space Photovoltaic Research and Technology Conference (SPRAT XIV), NASA CP-3324, Cleveland, OH, Oct 24-26, p. 4046.

Hosken, R. W., and Wertz, J. R., 2002, "Microcosm Autonomous Navigation System On-Orbit Operation," http://www.smad.com/analysis/mans1.html 
Hoskins, W. A., et al., 2002, "Direct Drive Hall Thruster System Study," 51st JANNAF Propulsion Meeting, Orlando, FL, November 19-21.

Jenkin, A. B., "Attitude Maneuvers of a Solar-Powered Electric Orbital Transfer Vehicle," AAS PAPER 91481, Jan 01, 1992.

Jones, P. A., et al., 1993, "A High Specific Power Solar Array For Low To Mid-Power Spacecraft," Proceedings of the 12th Space Photovoltaic Research and Technology Conference (SPRAT 12), May 01, p. 177-187.

Jongeward, G. A., et al., 2001, "High Voltage Solar Arrays for a Direct Drive Hall Effect Propulsion System," paper IEPC-01-327, 28th International Electric Propulsion Conference, Pasadena, CA, October.

Jongeward, G. A., et al., 2002, "Development of a Direct Drive Hall Effect Thruster System," paper 02PSC-77, SAE Power Systems Conference, Coral Springs, FL, Oct 29-31.

Jordan, C. E., 1989, "NASA Radiation Belt Models AP8 and AE-8," Report AD-A223660, Sep 30.

Kerslake, T. W., et al., 2000, "Solar Power System Options for the Radiation and Technology Demonstration Spacecraft," $35^{\text {th }}$ Intersociety Energy Conversion Engineering Conference, AIAA-20002807, Las Vegas, Nevada, July 24-28. (see also NASA TM-2000-210243).

Kessler, D. J., et al., 1989, "Orbital Debris Environment for Spacecraft Designed to Operate in Low Earth Orbit," NASA TM 100471.

Kessler, D. J., et al., 1996, "A Computer-Based Orbital Debris Model for Spacecraft Designs and Observations in Low-Earth Orbit," NASA TM 104825.

Kurland, R., et al., 2000, “Terra Flexible Blanket Solar Array Deployment, On-Orbit Performance and Future Applications," Proceedings of the IEEE Photovoltaic Specialists Conference, Anchorage, AK, Sep 17-22.

Laframboise, J.G. and Parker, L.W., 1973, "Probe Design for Orbit-Limited Current Collection," Phys. of Fluids, Vol. 16, No. 5, p. 629-636.
Marvin, D. C., 2000, "Assessment of Multijunction Solar Cell Performance in Radiation Environments," Aerospace Report \#TOR-2000(1210)-1, US Air Force Research Laboratory contract F04701-93-C0094, Feb 29.

Mason, L. S., and Oleson, S. R., 2000, "Spacecraft Impacts with Advanced Power and Propulsion," NASA TM-2000-209912, March.

Mikellides, Ioannis G., 2002, Science Applications International Corp., personal communication, December.

Moog Website, 2002, http://www.moog.com/Space/SpacecraftMechanism s/

Myers, R. M., and Manzella, D. H., 1994, "Stationary Plasma Thruster Plume Characteristics," NASACR-194454, Feb 01.

Myre, C. A., 1991, "Hypervelocity Particle Impact Testing of Solar Array Coupons," Preliminary Information Report \#259, NASA Lewis Research Center, May 30.

Reinhardt, K. C., et al., 1998, "Space Power Technology in Power Management and Distributions Electronics," Journal of Spacecraft and Rockets, Vol. 35, No. 6, November-December.

Sackett, L. L., et al., "Solar Electric Geocentric Transfer with Attitude Constraints: Analysis," NASA CR-134927, Aug 01, 1975.

Smith, R. E. and West, G. S., compilers, 1983, "Space and Planetary Environment Criteria for Use in Space Vehicle Development, 1982 Revision (Volume 1)," NASA TM-82478.

Spectrolab Website, 2002, http://www.spectrolab.com/prd/prd.htm

Wertz, J. R. and Larson, W. J., 1999, Space Mission Analysis and Design, $3^{\text {rd }}$ Ed., Microcosm Press, Torrance, CA and Kluwer Academic Publishers, Boston, MA, Sec. 11-1. 
Table 1.-_SEP Mission EPS Design Impacts

\begin{tabular}{|c|c|c|c|}
\hline Design Element & $\leq 120-V$ & 300-V & 300-V D2HET \\
\hline Battery Technology & $\mathrm{NiH}_{2}$ & Li Ion & Li Ion \\
\hline $\begin{array}{l}\text { Battery Location: DDCU } \\
\text { Input (high voltage) or } \\
\text { DDCU Output (low voltage) }\end{array}$ & Input & Output & Input \\
\hline $\begin{array}{c}\text { Payload Bus Regulation } \\
\text { (Sun/Eclipse) }\end{array}$ & Reg/Reg & Reg/Unreg $\quad$ Reg/Reg $\quad$ Reg/Reg & Reg/Reg \\
\hline $\begin{array}{l}\text { Thruster PPU Input Voltage } \\
\text { Regulation }\end{array}$ & Reg & Reg & $\begin{array}{l}\text { Reg via propellant } \\
\text { flow controller }\end{array}$ \\
\hline Power cable conductor gauge & Baseline & Smaller / 20 gauge lower limit & $\begin{array}{c}\text { Smaller / } 20 \text { gauge } \\
\text { lower limit }\end{array}$ \\
\hline Solar Array Power Harness & Baseline & Reduced \# traces, reduced $\Delta \mathrm{V} / \mathrm{V}$ & $\begin{array}{l}\text { Reduced } \# \text { traces, } \\
\text { reduced } \Delta \mathrm{V} / \mathrm{V}\end{array}$ \\
\hline ARU Present? & Yes & Yes & No \\
\hline PPU Efficiency (\%) & 90 & 90 & 95 \\
\hline PPU Input Power (kW) & 10.0 & 10.0 & 9.5 \\
\hline
\end{tabular}

Table 2.-Battery Design Inputs

\begin{tabular}{|c|c|c|}
\hline Design Feature & $\mathbf{N i H}_{\mathbf{2}}$ & $\mathbf{L i}$ Ion \\
\hline Maximum Cell Voltage (V) & 1.5 & 4.1 \\
\hline $\begin{array}{c}\text { Minimum Eclipse Time Bus Voltage } \\
(\% \text { of Sun Time Voltage Set point) }\end{array}$ & 75 & 75 \\
\hline \# of Cycles & 1000 & 1000 \\
\hline Recharge Ratio & 1.1 & 1.0 \\
\hline \# of Failed (Open-Circuited) Cells & 1 & 1 \\
\hline By-pass Diode Voltage Drop (V) & 0.7 & 0.7 \\
\hline Battery Round Trip Energy Efficiency \\
$(\%)$ & 79 & 85 \\
\hline $\begin{array}{c}\text { Design Temperature Limits }\left({ }^{\circ} \mathrm{C}\right) \\
\text { Minimum } \\
\text { Maximum }\end{array}$ & 0 & -5 \\
\hline
\end{tabular}

Table 3.-Design Impacts of System Voltage With Power Electronics Mass Scaling

\begin{tabular}{|c|c|c|c|c|c|c|c|}
\hline $\begin{array}{c}\text { Design } \\
\text { Characteristic }\end{array}$ & $\begin{array}{l}28-\mathrm{V} \\
\mathrm{NiH}_{2}\end{array}$ & $\begin{array}{l}50-\mathrm{V} \\
\mathrm{NiH}_{2}\end{array}$ & $\begin{array}{l}120-\mathrm{V} \\
\mathrm{NiH}_{2}\end{array}$ & Low-V/NiH & $\begin{array}{r}\text { 300-V } \\
\mathrm{NiH}_{2}\end{array}$ & Li Ion & $\begin{array}{c}\text { 300-V } \\
\text { D2HET } \\
\text { Li Ion }\end{array}$ \\
\hline \multicolumn{8}{|l|}{ EPS Masses (kg) } \\
\hline Solar Array & 253.2 & 198.6 & 167.2 & 159.1 & 153.9 & 153.9 & 148.3 \\
\hline Battery & 33.5 & 26.2 & 35.6 & 33.5 & 88.4 & 10.3 & 10.3 \\
\hline PMAD Boxes & 116.4 & 72.4 & 51.5 & 20.3 & 20.0 & 20.6 & 9.3 \\
\hline PMAD Cabling & 20.7 & 10.6 & 4.1 & 0.8 & 0.8 & 0.8 & 0.8 \\
\hline Total & $\overline{423.8}$ & $\overline{307.8}$ & $\overline{258.4}$ & 213.7 & 263.1 & 185.5 & $\overline{168.7}$ \\
\hline Array Wing Area $\left(\mathrm{m}^{2}\right)$ & 31.7 & 26.6 & 24.9 & 25.2 & 24.4 & 24.4 & 23.5 \\
\hline \# Solar Cells / String & 18 & 28 & 64 & 154 & 154 & 154 & 154 \\
\hline \# Array Strings / Wing & 624 & 336 & 138 & 58 & 56 & 56 & 54 \\
\hline $\begin{array}{c}\text { Battery Cell Capacity } \\
\text { (Amp-hrs) }\end{array}$ & 50 & 20 & 10 & 50 & 10 & 4.5 & 4.5 \\
\hline Battery \# Series Cells & 20 & 34 & 81 & 20 & 201 & 74 & 74 \\
\hline HET PPU Mass (kg) & 35 & 35 & 35 & 35 & 35 & 35 & 18 \\
\hline PPU Current (Amp) & 382 & 205 & 84 & 33 & 33 & 33 & 32 \\
\hline PPU Heat Rejection (W) & 1000 & 1000 & 1000 & 1000 & 1000 & 1000 & 500 \\
\hline $\begin{array}{c}\text { PPU Heat Rejection } \\
\text { Mass (kg) }\end{array}$ & 44 & 44 & 44 & 44 & 44 & 44 & 29 \\
\hline
\end{tabular}


Table 4.-Design Impacts of System Voltage With Improved Power Electronics Modeling

\begin{tabular}{|c|c|c|c|c|c|}
\hline $\begin{array}{c}\text { Design } \\
\text { Characteristic } \\
\end{array}$ & $\begin{array}{l}28-\mathrm{V} \\
\mathrm{NiH}_{2}\end{array}$ & $\begin{array}{l}50-\mathrm{V} \\
\mathrm{NiH}_{2} \\
\end{array}$ & $\begin{array}{l}120-\mathrm{V} \\
\mathrm{NiH}_{2} \\
\end{array}$ & $\begin{array}{l}\text { 300-V } \\
\text { Li Ion }\end{array}$ & $\begin{array}{c}\text { 300-V } \\
\text { D2HET Li Ion }\end{array}$ \\
\hline EPS Masses (kg) & & & & & \\
\hline Solar Array & 253.2 & 198.6 & 167.2 & 153.9 & 148.3 \\
\hline Battery & 33.5 & 26.2 & 35.6 & 10.3 & 10.3 \\
\hline PMAD Boxes & 132.4 & 110.7 & 96.6 & 90.9 & 57.3 \\
\hline PMAD Cabling & 24.5 & 12.1 & 6.8 & 5.6 & 5.6 \\
\hline Total & $\overline{443.6}$ & $\overline{347.6}$ & $\overline{306.2}$ & 260.7 & $\overline{221.5}$ \\
\hline
\end{tabular}

\begin{tabular}{|c|c|c|c|c|c|}
\hline $\begin{array}{c}\text { Design } \\
\text { Characteristic }\end{array}$ & $\begin{array}{l}28-\mathrm{V} \\
\text { Li Ion }\end{array}$ & $\begin{array}{l}50-V \\
\text { Li Ion }\end{array}$ & $\begin{array}{l}\text { 120-V } \\
\text { Li Ion }\end{array}$ & $\begin{array}{l}\text { 300-V } \\
\text { Li Ion }\end{array}$ & $\begin{array}{c}\text { 300-V } \\
\text { D2HET Li Ion }\end{array}$ \\
\hline EPS Masses (kg) & & & & & \\
\hline Solar Array & 126.6 & 104.0 & 92.9 & 85.6 & 80.4 \\
\hline Battery & 17.6 & 15.7 & 11.2 & 9.3 & 9.3 \\
\hline PMAD Boxes & 102.6 & 84.6 & 72.9 & 68.4 & 42.7 \\
\hline PMAD Cabling & 24.5 & 12.1 & 6.8 & 5.6 & 5.6 \\
\hline Total & 271.3 & 216.4 & 183.8 & 168.9 & 138.0 \\
\hline
\end{tabular}

(b) $\mathrm{SOA}+5$ years Technologies

Table 5.-EPS Design Impacts to ACS

\begin{tabular}{|c|c|c|c|c|c|}
\hline $\begin{array}{c}\text { Design } \\
\text { Characteristic }\end{array}$ & $\begin{array}{l}28-\mathrm{V} \\
\mathrm{NiH}_{2}\end{array}$ & $\begin{array}{l}\text { 50-V } \\
\mathrm{NiH}_{2}\end{array}$ & $\begin{array}{l}\mathrm{120-V} \\
\mathrm{NiH}_{2}\end{array}$ & $\begin{array}{l}\text { 300-V } \\
\text { Li Ion }\end{array}$ & $\begin{array}{l}\text { 300-V D2HET } \\
\text { Li Ion }\end{array}$ \\
\hline $\begin{array}{l}\text { Max. Spacecraft Mass Moment of Inertia } \\
\qquad\left(\mathrm{kg} / \mathrm{m}^{2}\right)\end{array}$ & 16479 & 16479 & 13436 & 12217 & 11474 \\
\hline $\begin{array}{l}\text { Max. Sum of Environmental Torques } \\
(\mathrm{N}-\mathrm{m})\end{array}$ & 0.0524 & 0.0373 & 0.0312 & 0.0291 & 0.0277 \\
\hline $\begin{array}{c}\text { Max. Roll Steering Torque } \\
(\mathrm{N}-\mathrm{m})\end{array}$ & 0.3264 & 0.2245 & 0.1831 & 0.1665 & 0.1564 \\
\hline $\begin{array}{l}\text { Max. Sum of Environmental Momentum } \\
\text { (N-m-sec / orbit) }\end{array}$ & 109.48 & 89.30 & 81.20 & 78.95 & 77.22 \\
\hline $\begin{array}{l}\text { Max. Roll Steering Momentum } \\
\text { (N-m-sec / orbit) }\end{array}$ & 39.17 & 26.95 & 21.97 & 19.98 & 18.76 \\
\hline $\begin{array}{l}\text { Number of Momentum Dumps / Day } \\
\text { BOL at } 400 \mathrm{~km} \text { altitude } \\
\text { EOL at } 35000 \mathrm{~km} \text { altitude }\end{array}$ & $\begin{array}{c}46 \\
9\end{array}$ & $\begin{array}{c}36 \\
9\end{array}$ & $\begin{array}{c}32 \\
9\end{array}$ & $\begin{array}{c}31 \\
9\end{array}$ & $\begin{array}{c}30 \\
9\end{array}$ \\
\hline
\end{tabular}

\begin{tabular}{|c|c|c|c|c|c|}
\hline $\begin{array}{c}\text { Design } \\
\text { Characteristic } \\
\end{array}$ & $\begin{array}{l}28-\mathrm{V} \\
\mathrm{NiH}_{2}\end{array}$ & $\begin{array}{l}\text { 50-V } \\
\mathrm{NiH}_{2} \\
\end{array}$ & $\begin{array}{l}120-\mathrm{V} \\
\mathrm{NiH}_{2}\end{array}$ & $\begin{array}{l}\text { 300-V } \\
\text { Li Ion }\end{array}$ & $\begin{array}{l}\text { 300-V D2HET } \\
\text { Li Ion }\end{array}$ \\
\hline $\begin{array}{l}\text { Max. Spacecraft Mass Moment of Inertia } \\
\qquad\left(\mathrm{kg} / \mathrm{m}^{2}\right)\end{array}$ & 6321 & 4975 & 4375 & 4209 & 3828 \\
\hline $\begin{array}{l}\text { Max. Sum of Environmental Torques } \\
(\mathrm{N}-\mathrm{m})\end{array}$ & 0.0181 & 0.0149 & 0.0135 & 0.0135 & 0.0125 \\
\hline $\begin{array}{l}\text { Max. Roll Steering Torque } \\
(\mathrm{N}-\mathrm{m})\end{array}$ & 0.0861 & 0.0678 & 0.0596 & 0.0574 & 0.0522 \\
\hline $\begin{array}{l}\text { Max. Sum of Environmental Momentum } \\
\text { (N-m-sec / orbit) }\end{array}$ & 71.12 & 64.39 & 61.30 & 62.08 & 59.45 \\
\hline $\begin{array}{l}\text { Max. Roll Steering Momentum } \\
\text { (N-m-sec / orbit) }\end{array}$ & 10.34 & 8.13 & 7.15 & 6.88 & 6.26 \\
\hline $\begin{array}{c}\text { Number of Momentum Dumps / Day } \\
\text { BOL at } 400 \mathrm{~km} \text { altitude } \\
\text { EOL at } 35000 \mathrm{~km} \text { altitude }\end{array}$ & $\begin{array}{c}26 \\
9\end{array}$ & $\begin{array}{c}23 \\
9\end{array}$ & $\begin{array}{c}21 \\
9\end{array}$ & $\begin{array}{c}21 \\
9\end{array}$ & $\begin{array}{c}20 \\
9\end{array}$ \\
\hline
\end{tabular}

(b) $\mathrm{SOA}+5$ years EPS Technologies 


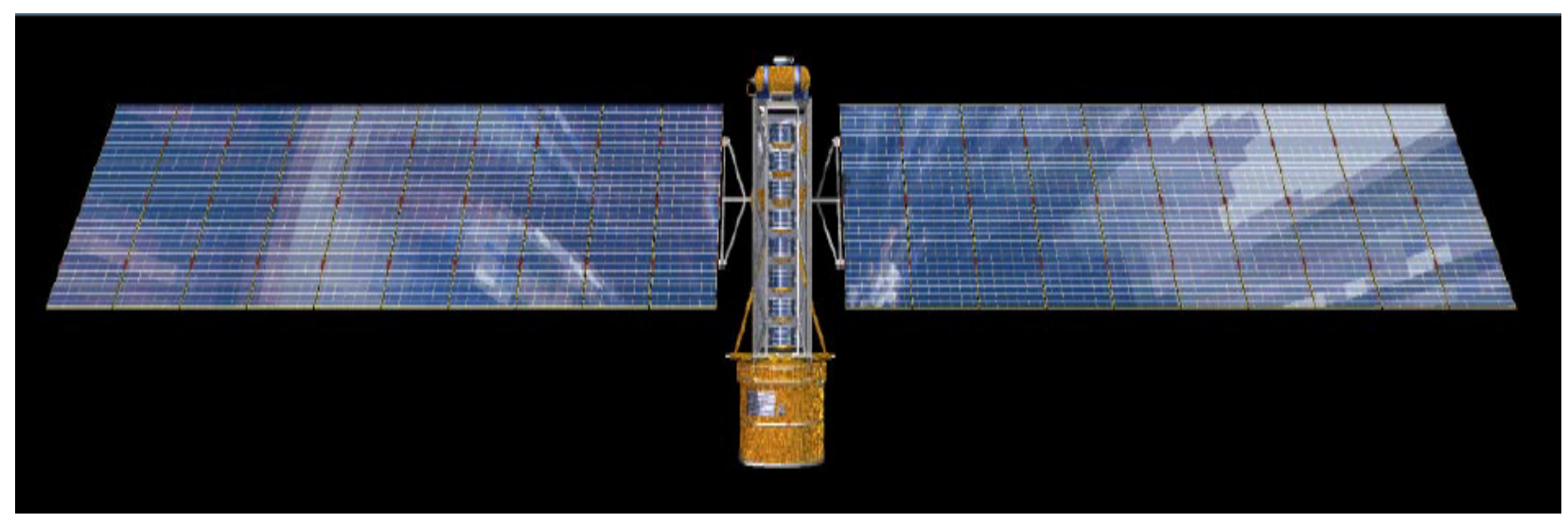

Figure 1.-Conceptual SEP Mission Spacecraft

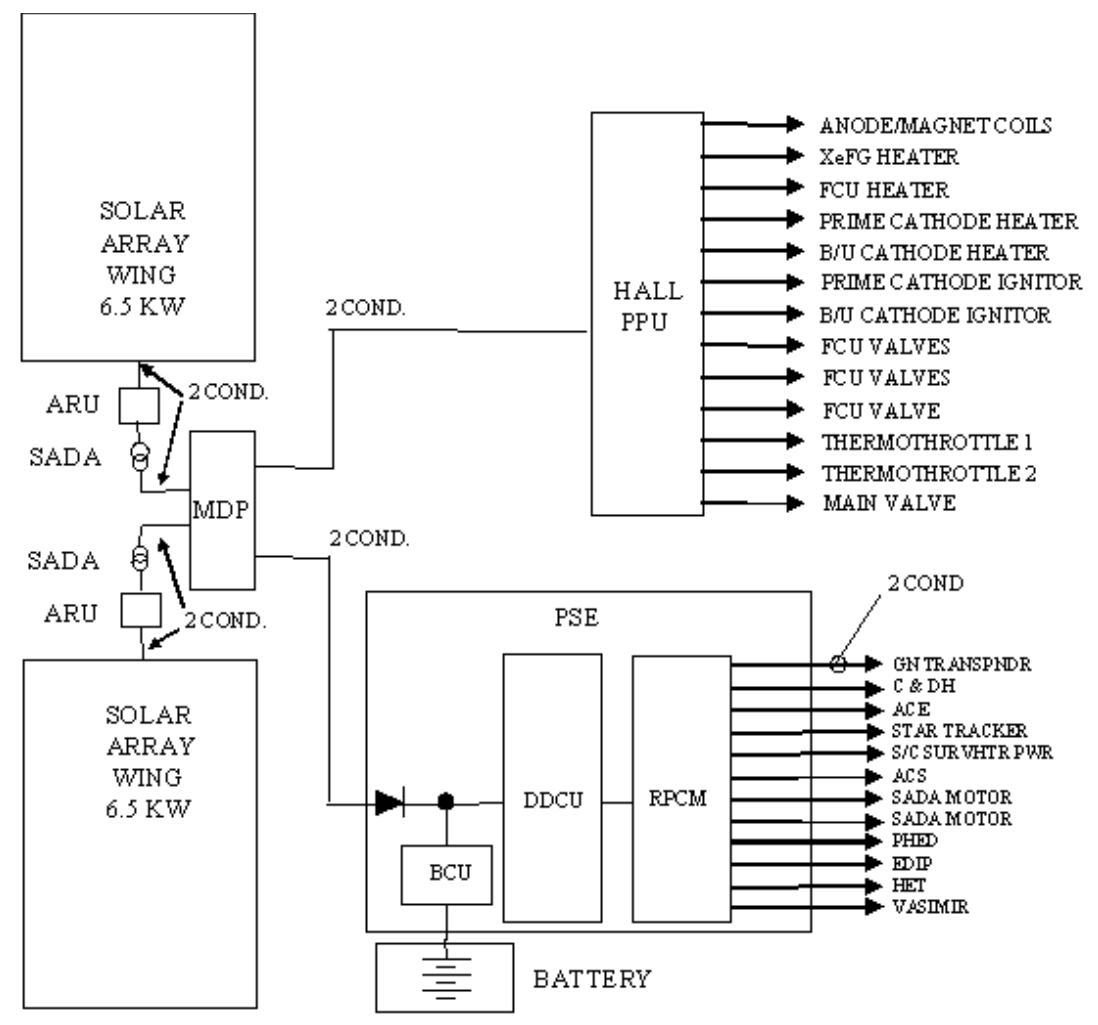

Figure 2.-PMAD Architecture 


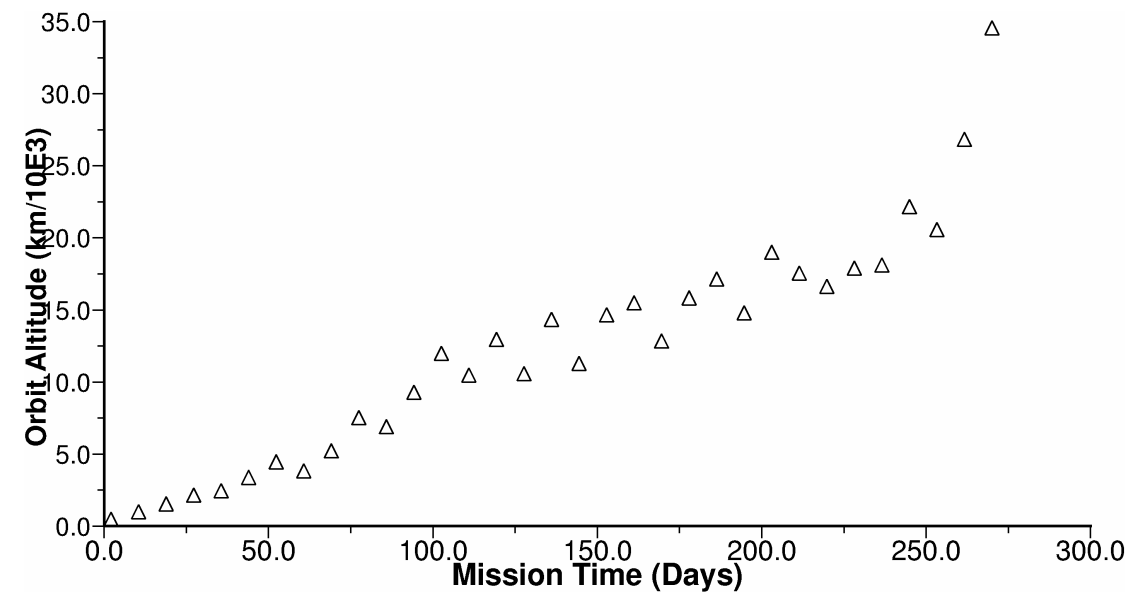

Figure 3.-Mission Orbital Altitude History

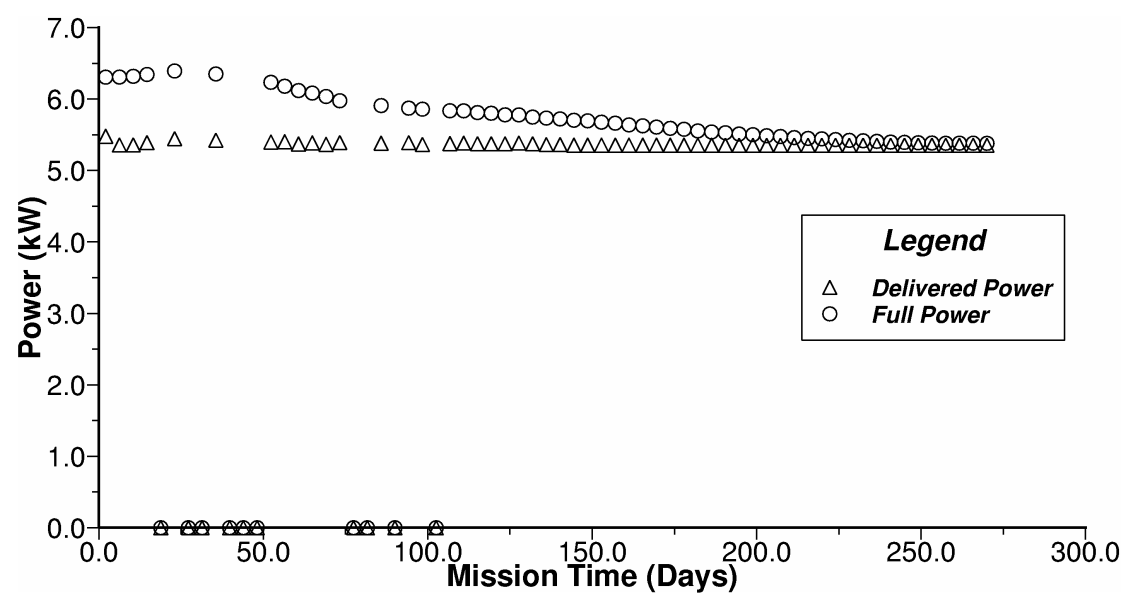

Figure 4.-Photovoltaic Wing Power

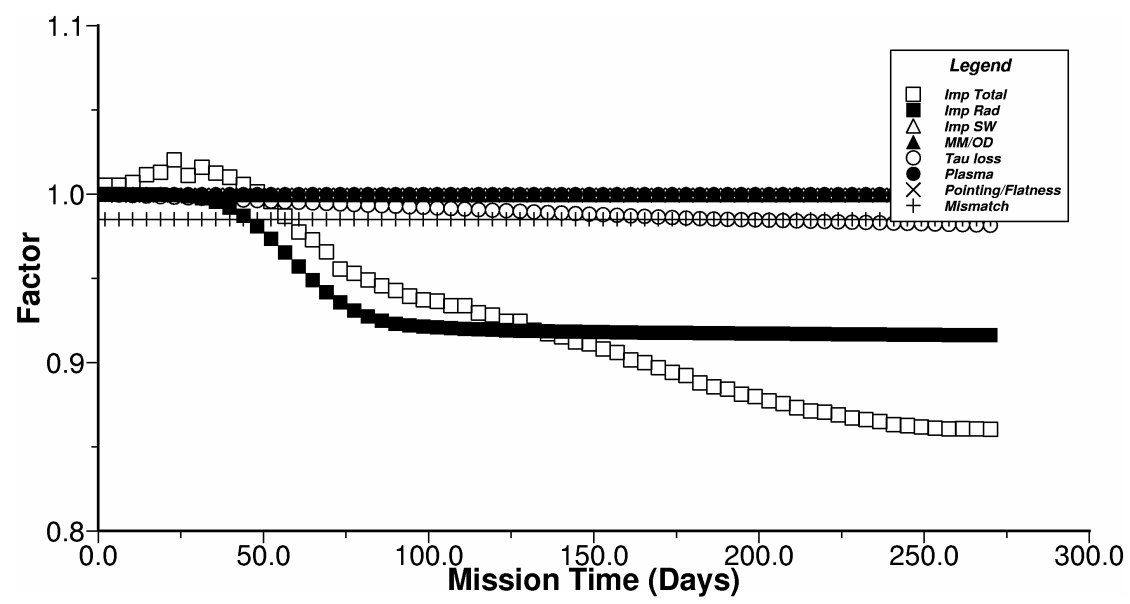

Figure 5.-Photovoltaic Wing Degradation 


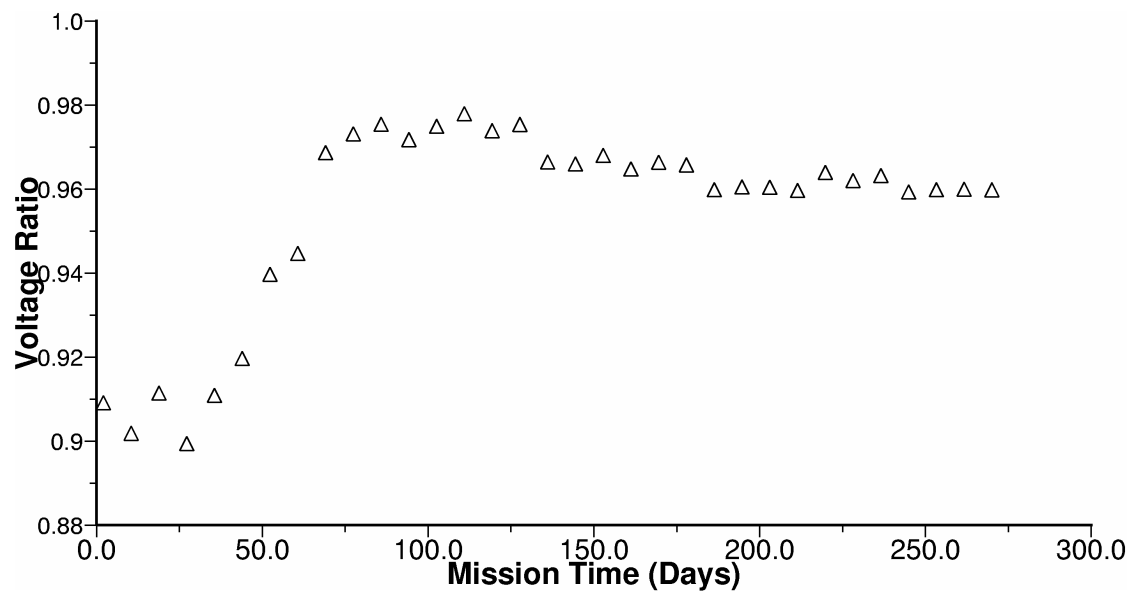

Figure 6.-Photovoltaic Wing Operating Voltage

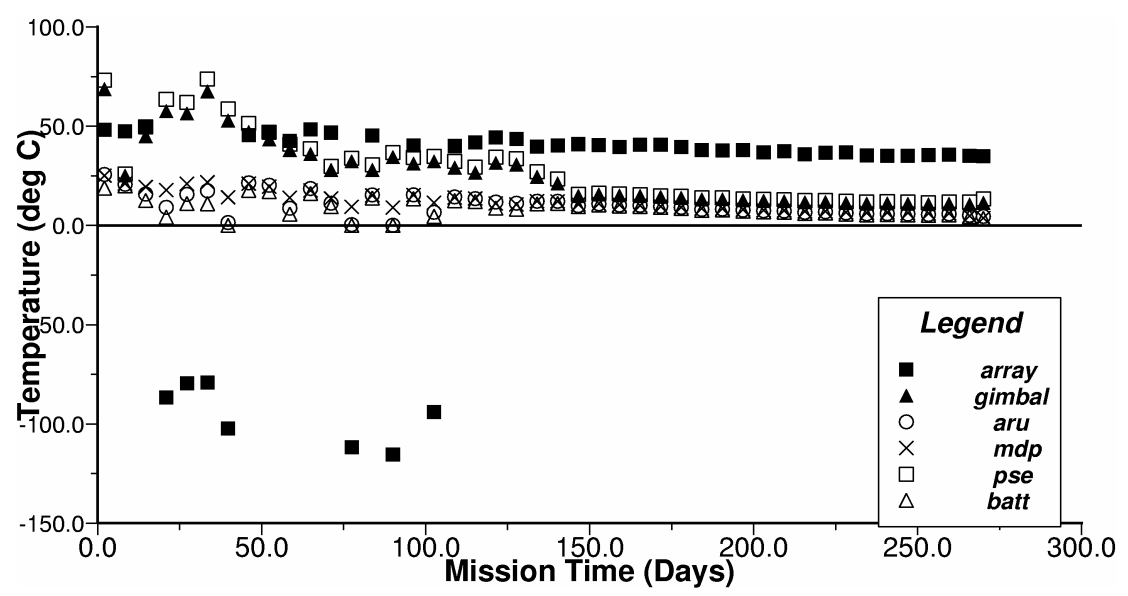

Figure 7.-EPS Component Temperatures 
Public reporting burden for this collection of information is estimated to average 1 hour per response, including the time for reviewing instructions, searching existing data sources, gathering and maintaining the data needed, and completing and reviewing the collection of information. Send comments regarding this burden estimate or any other aspect of this collection of information, including suggestions for reducing this burden, to Washington Headquarters Services, Directorate for Information Operations and Reports, 1215 Jefferson Davis Highway, Suite 1204, Arlington, VA 22202-4302, and to the Office of Management and Budget, Paperwork Reduction Project (0704-0188), Washington, DC 20503.

\begin{tabular}{|l|l|l}
\hline 1. AGENCY USE ONLY (Leave blank) & $\begin{array}{c}\text { 2. REPORT DATE } \\
\text { April } 2003\end{array}$ & $\begin{array}{r}\text { 3. REPORT TYPE AND DATES COVERED } \\
\text { Technical Memorandum }\end{array}$ \\
\hline
\end{tabular}

4. TITLE AND SUBTITLE 5. FUNDING NUMBERS

Effect of Voltage Level on Power System Design for Solar Electric Propulsion Missions

\section{AUTHOR(S)}

Thomas W. Kerslake

WBS-22-755-12-16

\section{PERFORMING ORGANIZATION NAME(S) AND ADDRESS(ES)}

National Aeronautics and Space Administration

John H. Glenn Research Center at Lewis Field

Cleveland, Ohio 44135-3191

8. PERFORMING ORGANIZATION REPORT NUMBER

E-13876

\section{SPONSORING/MONITORING AGENCY NAME(S) AND ADDRESS(ES)}

National Aeronautics and Space Administration

Washington, DC 20546-0001

10. SPONSORING/MONITORING AGENCY REPORT NUMBER

NASA TM-2003-212304

\section{SUPPLEMENTARY NOTES}

Prepared for the International Solar Energy Conference cosponsored by the American Society of Mechanical Engineers' Solar Energy Division, Japan Society of Mechanical Heat Transfer Division, Japan Solar Energy Society, Korean Solar Energy Society, and CSIRO Australia, Kohala Coast, Hawaii, March 15-18, 2003. Responsible person, Thomas W. Kerslake, organization code 6920, 216-433-5373.

Unclassified - Unlimited

Subject Categories: 18 and 20

Distribution: Nonstandard

Available electronically at http://gltrs.grc.nasa.gov

This publication is available from the NASA Center for AeroSpace Information, 301-621-0390.

\section{ABSTRACT (Maximum 200 words)}

This paper presents study results quantifying the benefits of higher voltage, electric power system designs for a typical solar electric propulsion spacecraft Earth orbiting mission. A conceptual power system architecture was defined and design points were generated for system voltages of $28-\mathrm{V}, 50-\mathrm{V}, 120-\mathrm{V}$, and $300-\mathrm{V}$ using state-of-the-art or advanced technologies. A 300-V "direct-drive" architecture was also analyzed to assess the benefits of directly powering the electric thruster from the photovoltaic array without up-conversion. Fortran and spreadsheet computational models were exercised to predict the performance and size power system components to meet spacecraft mission requirements. Pertinent space environments, such as electron and proton radiation, were calculated along the spiral trajectory. In addition, a simplified electron current collection model was developed to estimate photovoltaic array losses for the orbital plasma environment and that created by the thruster plume. The secondary benefits of power system mass savings for spacecraft propulsion and attitude control systems were also quantified. Results indicate that considerable spacecraft wet mass savings were achieved by the $300-\mathrm{V}$ and $300-\mathrm{V}$ direct-drive architectures.

\section{SUBJECT TERMS}

Electric power; Solar arrays; Electric batteries; Solar electric propulsion; Electronic equipment; Plasma (physics); Orbit transfer vehicles; Performance prediction

\begin{tabular}{|c|c|c|}
\hline $\begin{array}{c}\text { 17. SECURITY CLASSIFICATION } \\
\text { OF REPORT } \\
\text { Unclassified }\end{array}$ & $\begin{array}{c}\text { 18. SECURITY CLASSIFICATION } \\
\text { OF THIS PAGE } \\
\text { Unclassified }\end{array}$ & $\begin{array}{c}\text { 19. SECURITY CLASSIFICATION } \\
\text { OF ABSTRACT } \\
\text { Unclassified }\end{array}$ \\
\hline
\end{tabular}

15. NUMBER OF PAGES 20

16. PRICE CODE 20. LIMITATION OF ABSTRACT 